\title{
Nyhedernes musik
}

\author{
Af Nicolai Jørgensgaard Graakjær
}

\begin{abstract}
På trods af, at funktionel musik spiller en vigtig rolle i medierne, er musikkens 'strategiske' funktioner ikke specielt vel belyst $i$ hverken medieforskningen eller markedsforskningen. Artiklen neranalyserer 23 sekunders underlegningsmusik til TV2 Nyhedernes introduktion en tilfeldig aften og belyser $i$ samklang med Jorgen Stigels artikel, hvorledes nyhedernes musik tager karakter af egenreklame: Musikken er 'lytfang' og auditivt klister - en dynamisk instans, som skaber stemningsmassig sammenhang $i$ nyhedernes forskrap. Musikken må vare distinktiv, skabe opmarksomhed og gøre nyhederne identificerbare både i forhold til de omgivende reklamer på kanalen, andre tv-kanalers nyhedsudsendelser og hverdagslige goremål $i$ brugssituationen.
\end{abstract}

"God aften og velkommen til Nyhederne". Per Christiansen, studieværten denne aften, kigger os i øjnene med et mildt og venligt ansigtsfold; han fortsætter med aftenens hovedoverskrift: "'Brug flere penge', hoornår har man sidst hort det fra en finansminister?"'. Datoen er den ellevte december 2003, og klokken er ca. 19:00 - TV2's nyheder er i gang, og vi er $813.000^{1}$, der kigger med.

'Kigger' er dog ret beset ikke det eneste, vi gør, for vi lytter selvfølgelig også med varierende grader af interesse til aftenens hovedbudskab. Spidses ørerne, kan der tilmed anes efterklange fra en netop afrundet musik. Musikken har ledsaget et introduktionsforløb forud for studieværtens velkomst. I de 23 sekunder, som introduktionen har varet, er vi først blevet præsenteret for studieværten siddende perifert i et halvoplyst redaktionslokale og siden for et forskræp med aftenens tophistorie pakket ind i billeder fra den travle julehandel. Indimellem har et animeret logo optrådt som overgang. Det er den uafbrudt ledsagende musik, som skal være omdrejningspunktet for nærværende artikel; musikken som siden 1. maj 1998 har været fast inventar ${ }^{2}$ under hver eneste nyhedsintroduktion ${ }^{3}$ : hvad er det dog, musikken laver her?

Som svar på denne undren vil artiklen udfolde en nærlytning af Nyhedernes introduktionsmusik. Specifikt skal det forsøges anhørliggjort, hvorledes det aktuelle musikalske bidrag har stor betydningsmæssig vægt som iscenesættelse af Nyhederne (en betydning som, trods det at Nyhederne er Danmarks for tiden mest sete program med fast musikalsk profilering ${ }^{4}$, ikke synes velundersøgt $t^{5}$ ), og mere generelt skal de stra- tegisk kommunikative implikationer ved denne iscenesættelse diskuteres. Nyhedernes musik kan betragtes som en strategisk kommunikation med det formål at tiltrække og fastholde seere i forhold til det aktuelle program og jo - nok så vigtigt - de omkransende reklameblokke. Indledningsmusikken bliver således del af Nyhedernes og, i et videre perspektiv, TV2's egenreklame, og hermed åbner musikforekomsten for mere principielle diskussioner vedrørende markedskommunikativ brug af musik.

Indledningsvist skal problematikker om musikkens 'betydning' introduceres. Det er i den forbindelse ærindet at kvalificere omtalen af 'musik som kommunikation' og dermed at optegne teoretisk udgangspunkt for den efterfølgende analyse.

\section{Musik og betydning}

Musik og betydning har været genstand for megen undersøgelse og ikke mindst polemisering ${ }^{6}$, og det er ikke nogen enkel sag at skulle analysere dette forhold. Spørgsmålet om musikalsk betydningsdannelse kan dog, lidt fortegnet, opstilles som: Refererer musik til noget andet 'end sig selv' (f.eks. følelser), eller må og kan musik kun forstås i relation 'til sig selv'? (undertiden omtalt som henholdsvis heteronomiæstetik vs. autonomiæstetik (Benestad, 1978) eller expressionism vs. formalism (jf. f.eks. DeNora, 1986)).

I det følgende skal udgangspunktet for analysen være, at det musikalske udtryk har et immanent betydningspotentiale, og på den måde knyttes der an til et heteronomiæstetisk udgangspunkt. En vigtig pointe er imidlertid, at dette potentiale altid 
finder udfoldelse i en aktuel kontekst, og at denne kontekst har stor relevans for den aktuelle oplevelse. Erkendelsen af kontekstens relevans - og ikke mindst anerkendelsen af studiet heraf - er først i de senere år kommet på den musikvidenskabelige dagsorden (således har heteronomiæstetikere historisk set også negligeret kontekst, og fokus har været på musikalske strukturelementer som betydningsbærende enheder ${ }^{7}$ ). Som antydet (i note 5) har den musikvidenskabelige forskning længe haft en kompromitterende grundtone i sin tilgang til studiet af musik som 'funktion'; Typisk har funktionelle musikforekomster været opfattet som 'mindre værdifulde" (f.eks. Steiner-Hall, 1987), og 'mere værdifuldt' har været den musik, der er tiltænkt et opmærksomt lyttende publikum i koncertsalen - eller med Kermans ord: "...Western music in the high-art tradition" (Kerman, 1985, s. 11). Hverdagsmusikforbrug er dog så omsiggribende og betydningsfuld, at en negligering - eller en afvisning af samme som musikmisbrug - vil være meget amputerende for forståelse for musik (jf. f.eks. DeNora, 1986, 2000 og Clayton, Herbert \& Middleton, 2003).

Musiks betydningspotentiale kan forstås som konstitueret ved, at de musikalske strukturer er intenderet og arrangeret af et menneske ${ }^{9}$. I denne proces kan subjektet siges mere eller mindre reflekteret at aflejre eller forstærke momenter af sin kollektive musikalske habitus ${ }^{10}$. Det musikalske udtryk kan dermed siges at være inficeret med mening," ${ }^{\text {"11 }}$ Den amerikanske musikfilosof $\mathrm{Su}-$ zanne Langer knytter an til denne betragtning, når hun taler om musik som udtrykkende en art følelsernes morfologi (Langer, 1979); at musik udfolder sig i tid og har bevægelsesattributter såsom spænding, gentagelse, forløsning, omskiftelighed o. lign. ${ }^{12}$. Langer omtaler dette som musikkens 'symbolske karakter'. Med inspiration hos Langer kan man anføre, at der i mødet mellem det musikalske udtryk og det menneskelige indtryk kan opstå en samtidsillusion eller med Nielsens (1998) ord: at der er 'korrespondens' mellem musik og menneske. På denne baggrund kan musik invitere og henføre os i landskaber (eller på nudansk: soundscapes), hvor nogle 'oplevelsesstier' lader sig mere umiddelbart betræde end andre. Musik kan således siges at have kraftige 'imperativer'. Disse 'imperativer' kvalificeres, som nævnt, i en aktuel kontekst; tilhørerens meningsdannelse afhænger i vid udstrækning af, hvorvidt tilhøreren tilhører
- eller identificerer sig i et forhold til - den kollektive habitus, som det musikalske udtryk anslår. Med andre, mere specifikke begreber: hvorvidt tilhøreren er kodekompetent (har kendskab til den musikalske stil og genre), og om hvorvidt der indtræder kodeforstyrrelser (om stil og genre bryder med forventninger og normer i den aktuelle kontekst). Disse koder etableres og reproduceres som en del af en musikalsk socialisering, som for det vesterlandske menneske især finder sted i forbindelse med medierede musikforekomster (i f.eks. film, reklamer, TV-serier, populær vokalmusik) og rituelle handlinger (f.eks. bryllup og begravelse). Det betyder ikke dermed, at musikalsk mening kun kan tilskrives abstrakte konstruktioner i hovederne på situerede lyttere, sådan som eksempelvis DeNora undertiden kommer til at fremstille $\operatorname{det}^{13}$. Som også nævnt må det anerkendes, at musikalske udtryk kan have ubarmhjertige imperativer - for eksempel vil det være usandsynligt at kunne opleve opadgående, accelererende, rytmisk intensiverede og crescenderende melodibevægelser som andet end spændingsopbyggende. En foreløbig konklusion vil her være, at musikalsk betydning finder udfoldelse $i$ mødet mellem et musikudtryk og et menneskeindtryk, situeret i en specifik kontekst. I en vis forstand er dette møde altid af intersubjektiv karakter - i det musikalske udtryk fremtoner så at sige en anden menneskelighed.

\section{Forankrende afløsning}

Men hvordan så indfange dette i en analyse af, hvad musikken laver i nyhederne? Vigtigt er det her at understrege, at musikken kvalificeres og kvalificerer i et gensidigt afhengighedsforhold til den intermediale kontekst, og med inspiration i Barthes terminologi vil det sige, at musikken har både forankrende og aflosende funktion ${ }^{14}$, men også (til nuancering af Barthes' udlægning, oprindeligt formuleret om forholdet mellem billede og tekst) at disse funktioner er fortløbende og gensidige ${ }^{15}$ og kun kan abstraheres via perspektivtagninger i analysen. Som det nu er antydet, skal analysen være semiotisk inspireret ${ }^{16}$. Et umiddelbart vilkår og mulig begrænsning for en sådan analysevinkel er det forhold, at musik, som tegnsystem betragtet, kan karakteriseres ved at være 'løs i koderne' derved ikke at kunne frembyde sprogets dobbeltartikulation ${ }^{17}$. Det hedder sig for eksempel, at musikalske tegn er polysemiske (derved at be- 
tydningen er 'vag, multipel, varieret, forvirrende' (Nattiez, 1990, 37)), at musik udtrykker en 'ren konnotationel semantik' (derved at skulle 'mangle' sprogets denotative betydningsforankring; Langer, 1979, 101) og i forlængelse heraf, at musik faktisk er et amputeret tegnsystem repræsenterende 'signifiers without signified' (en saussure'sk betragtning, gengivet i DeNora, 1986, 87) - alt sammen udtryk for musikanalysens besværligheder med at måtte inddæmme de 'strømmende' konnoterede meninger.

Når en semiotisk inspireret analyse alligevel, trods disse tilsyneladende svære odds, skal være udgangspunkt, er det begrundet i det forhold, at det musikalske objekt ikke er interessant 'i sig selv'. Nattiez og Langer synes at implicere, at det musikalske objekt optræder 'vakuumpakket', og de føjer sig, hvad angår denne musikforståelse, ind i den udbredte, og tidligere omtalte, musikvidenskabelige tradition, som ikke har tilstrækkelig sans for kontekstuelle forholds vægtige betydning til forståelse for musikalske meningsdannelse. I det aktuelle tilfælde skal analysegenstanden forstås som kontekstindlejret på tre niveauer: Sociokulturelt (i et vestligt samfund), situationelt (TV-reception) og multimedialt (audiovisuelt udtryk), og disse sammenhænge vil alle blive forsøgt medtænkt $i$ analysen.

Analysefremstillingen skal, mere konkret, være inspireret af populærmusikforskeren Phillip Tagg, der har undersøgt musikalsk betydningsdannelse i populærmusikalske udtryk (f.eks. signaturmusikken til Kojak (1979a) og Abba's Fernando (1979b)). Inspireret af en pierciansk tegntypologi fremstiller Tagg et begrebs- og forståelsesmæssigt solidt udgangspunkt for studiet af musikalsk betydningsdannelse med relevans for den aktuelle analyseinteresse. Tagg fremhæver musemet ${ }^{18}$ som "a minimal unit of musical discource that is recurrent and meaningful in itself within the framework of any one musical genre" (Tagg, 1998, s. 32), og den musikalske analyse vil dermed dreje sig om at identificere $\mathrm{e}^{19} \mathrm{og}$ fortolke disse musemer indenfor rammerne af tegntypologien. Den musikalske betydningsdannelse vil karakteriseres dels i forhold til de ressourcer, som det audiovisuelle udtryk 'stiller til rådighed', og dels i forhold til den aktualiserede musikalske habitus. Hos Tagg tematiseres dette med begreberne genre synecdoche (sammenlignelige med Peirce's indeks), style indicator (sammenlignelige med det Peirce's symbol), og anaphones (sammenlignelig med Peirce's ikon) indføres som begreb om musikkens evne til dels at efterligne 'ikke-musikalsk' lyd (musikalsk onomatopoietikon eller sonic anaphone) samt dels at illudere kropslige, fysiologiske oplevelseskvaliteter (tactile og kinetic anaphones) - sidstnævnte også tydeligt inspireret af Langers 'symbol'20, tidligere omtalt.

\section{3 sekunders musik}

Og lad os så spole tiden ca. 23 sekunder tilbage i forhold til Per Christiansens velkomst. I en vis forstand skal det følgende være et forsøg på at kvalificere vores oplevelse; et forsøg på, via en nærlytning, at anhørliggøre og reflektere en oplevelse, som måske ellers ikke, i det daglige trummerum, tilkendes megen overvejelse ${ }^{21}$.

Introduktion udfolder sig i tre sekvenser - en åbning, et forskræp, en velkomst - og instrumental musik ledsager, som nævnt, uafbrudt (jf. den skematiske fremstilling). Billedmæssigt er der klare brud mellem de tre sekvenser, idet et animeret logo indføjes som kort mellembillede. Logoet er karakteriseret ved en figur (sort/hvid firkant midt i billedet med teksten "TV2- Nyhederne"), der optræder på en grund af rødlige (øverste billedhalvdel) samt råhvide (nederste billedhalvdel) farvenuancer, og som baggrund anes en langsomt roterende jordklode. Som del af grunden er der i skæringspunktet mellem de to billedhalvdele en række små firkanter, der bevæger sig i rækker mod venstre i billedet, og fire strenge slynger sig vertikalt. Det er netop i overgangen mellem sekvenserne, at det musikalske bidrag er særligt iørefaldende: lydstyrken er forøget, der optræder melodisk materiale, og der er ikke andre hørbare lyde (som f.eks. voice-over eller reallyde). Musikken bliver her, sammen med logoet, programprofileringens hovedhjørnestene.

0-5. sekund: Under åbningen introducerer dybe, regelmæssige paukeslag ( $\mathrm{ml}$ ) en langsom puls (28 pulsslag i minuttet; fornemmes langsomt i forhold til den normale hjerterytme på 60-80). Visuelt optræder paukeslaget synkront med, at en cirkel af sorte prikker, der bevæger sig fra udkanten af skærmen mod et ufikseret sted ca. midt i billedet, forsvinder fra billedet - som om det er prikkerne, der frembringer paukeslaget på overfladen af jordkloden (der anes i billedets øverste og nederste halvdel $)^{22}$. Klangmæssigt er det musikalske udtryk spagfærdigt; det dybe paukeslag klinger kun meget kortvarigt (på tonen 
as), og derudover høres i et relativt højt leje en stacceret klangbrydning ( $\mathrm{m} 2)$ spillet (over tonerne es, f og b) af en blandingsklang, der involverer et strengeinstrument (formentlig harpe og el-piano). Klangbrydningen opleves som 'flimmer'; der er ikke melodisk retning eller prægnans, og den fremtoner dermed som en pendant til det visuelle udtryks fire flimrende 'strenge' midt i skærmen. Tonalt defineres samlet en kvartklang (f-b-as-es) (m3), der ikke fordrer tonal opløsning.

5.-6. sekund: Fra under åbningen at have fungeret som grund, bliver det musikalske udsagn, i overgangen til forskræppet, kortvarigt figur. Denne musikalske intensivering indtræder synkront med billedets skift fra åbning til forskræp (medieret af den korte tilsynekomst af logoet, tidligere omtalt). Fremtoningen af baslinje, introduktionen af et melodisk monofont motiv (m4) og lilletrommerytmer i 1/16's-underdeling (m5) intensiverer det musikalske indtryk; som en episodisk markor fungerer disse musikalske tiltag som en optakt: de skaber 'drive', retning og forventning. Pulsfornemmelsen opfattes nu som hurtig (lilletrommens markeringer definerer nu fire slag i takten), tonalt defineres et klart centrum (c-tonalitet, introduceret via ledetonen des og via $\mathrm{m} 4$, der formuleres som tre opadgående spring over en c-tonalitets grundtrin: prim, kvart, kvint, oktav), og klangligt er motivet gennemtrængende (foredrages marcato og kraftigt af en piano-basun blandingsklang). Motivet har 'signal'- og 'fanfare'-præg og får her en slags reveille-funktion - det vækker og påkalder sig, og dermed det billedmæssige just forestående (dagens tophistorie), opmærksomhed.

7.-17. sekund: under forskræppet fungerer musikken igen som grund, men nu af en mere 'hektisk' og 'fremadskridende' karakter: elementer fra den episodiske markør finder fast udfoldelse: lilletromme markering af alle taktens slag (m5) og basfigur (m6) med tydelig markering af grundtonen (c); pulsfornemmelsen tydeliggøres yderligere med stortromme slag på 2-slaget ( $\mathrm{m} 1)$, og basfigurens accentuering af 2 og-slaget bevirker rytmisk spændstighed. Harmonisk forstærkes indtrykket af det tonale centrum via en vagt anet strygersynth-akkord i et midterleje. Mod slutningen af forskræppet synkroniseres en musikalsk episodisk markering atter med logoets begyndende fremtoning: et monofont, crescenderende opadgående oktavspring $(\mathrm{m} 7)$ vokser frem af strygerklangen, $\mathrm{og}$ basfiguren varieres $(\mathrm{m} 6)$.
17.-23. sekund: Herefter indtræder nyhedernes egentlige jingle ${ }^{23}$ og dermed den 'hook-line', som endegyldigt skal fange vores opmærksomhed. Signalmotivet toner atter frem (transponeret en kvart ned), men nu tilføjes et motiv (m8) som afrunding: trinvise, hastige, nedadgående bevægelser skaber modvægt og forløsning i forhold til signalmotivets erigerede fremtoning $(\mathrm{m} 4)$. Det tilføjede motiv definerer nu (via præsentationen af tertsen) tonekønnet (c-dur). Motivet afsluttes på grundtonen, men flere andre forhold (end rent melodiske) bevirker, at musikken ikke just nu finder hvile: Dels indtræder det afsluttende tone synkoperet (på 4og-slag med overbinding til efterfølgende 1-slag), dels fastholdes en hektisk puls (nu, i forhold til forskræppet, yderligere intensiveret med stortromme på alle fire slag og markering af $1 / 16$ i en maracas-rytme (m9)), og dels ledsages den afsluttende tone af en harmonisk udtryksfuld afledning (m10) (til as-dur introduceret ved bassens trinvise nedgang (c-bas)) - den afsluttende tone klinger nu mere ustabilt som dramatiseret dur-terts og ikke som grundtone. Den harmoniske afledning fremstår her som et spændingsmoment ${ }^{24}$, der - i sammenhæng med melodiske fordoblinger og oktaveringer $(\mathrm{m} 7)$ af tonen c (under tilføjelse af diverse messingblæsere (trompet, basun, horn)) samt et hurtigt accelererende crescendo - afføder en kraftig potensering af det musikalske udtryk. Udtrykket bliver en vægtig episodisk markør, der udpeger, at nu er velkomsten nært forestående.

På 1-slaget i den følgende takt finder den ophobede spænding en markeret forløsning på en eksalteret grundakkord (c-dur) (ml1); musikkens toptone (c'et to oktaver over motivets c) optræder her i trompeter med stor kraft - afrundet med et lille opadgående melodisk svirp ${ }^{25}$ - ledsaget af bastoner og diverse slagtøj. Det er netop da, at studieværten toner frem på billedet via en hurtig indzoomning (så studieværten fokuseres i nærbillede). Indzoomningen foretages netop, som den musikalske potensering og 'spændingsophobning' tager fart (fra 2-slaget i takten). Umiddelbart efter den musikalske kulmination på 1-slaget byder studieværten velkommen; den markerede akkord klinger ud kort ind over speaken, og vagt høres, som en reminiscens fra åbningen, den 'flimrende' klangbrydning $(\mathrm{m} 2)$ - nu transponeret, så den opleves 'roligere' (derved tonalt at måtte høres i lyset af den kort forinden tydeligt definerede c-dur). 


\section{Efterklange}

Men hvad er det så, musikken bidrager med her? For en umiddelbar betragtning bidrager musikken på et syntaktisk niveau ved at agere 'auditivt klister', der manifesterer kontinuitet over sekvenser, som visuelt ikke har stærk sammenhængskraft (forskræppet er f.eks. præget af divergerende farver og former i forhold til studieindretning og logo). Men det er kun en lille del af musikkens samlede bidrag; i det følgende skal yderligere bidrag pointeres; nemlig at musikken dels presenterer nyhederne ('Nu er Nyhederne her...'), og dels representerer nyhederne ('...og de har den og den karakter og kvalitet'). Disse to funktioner må i praksis forstås som sammenhængende (enhver form for præsentation indebærer en vis grad af repræsentation og omvendt), og i det følgende må det forstås sådan, at én af funktionerne kan være dominerende.

Presentationen tager sig i indledningsforløbet overordnet ud som en bevægelse fra 'fjern, ude, vag' til 'nær, inde, klar'. På billedsiden opleves dette i skiftet fra åbningens panorama over et halvoplyst redaktionslokale (hvor studieværtens kun anes perifert under dele af det animerede logo) til velkomstens indzooming på den nu projektørbelagte og fokuserede studievært (nu i 'øjenhøjde' og 'øjenkontakt' med seeren). På speak-siden kommer det udtryk i skiftet fra kanalstemmens voiceover i åbningen, over studieværtens forskræp-speak til den direkte adressering i velkomsten ${ }^{26}$. Det musikalske bidrag formidler disse skift og forstærker oplevelsen af dem via en intensivering, der netop propelviseres i overgangen mellem de tre sekvenser (jf. de episodiske markører). Fire fremtrædende musikalske delgestalter ${ }^{27}$ (puls, klang, melodik og tonalitet; repræsenterende syntagmatic museme compounds) er alle medvirkende til denne horisontale intensivering: pulsmassigt og rytmisk formuleres en stadig øget spænding via accentueringernes øgede frekvens og volumen (m1 m5 m9), klangligt afløses fjern, spag 'flimmer' af prægnans ( $\mathrm{ml}$ m2 m4 m8 m11), melodisk afløses retningsløs, pletvis klangbrydning af afrundet, bueformet kurvatur (m2 m4+m8), og tonalitetsmessigt afløses svævende tonalitetsfornemmelse af sikker og entydig ditto (m3 $\mathrm{m} 6 \quad \mathrm{~m} 7 \quad \mathrm{~m} 7 \quad \mathrm{~m} 10 \quad \mathrm{~m} 11)$.

De musikalske udsagn formulerer sig i dette perspektiv som taktile og kinetiske anafoner. Musikken tilføjer således det samlede udtryk en bevægelse, dynamik, intensitet og progression, som de billedlige og verbale sekvenser ikke ene kan etablere. Bidraget kan nok siges at være noget, som musikken 'gør ved billedet', men billedet kan, som tidligere nævnt, alligevel siges at forankre betydningspotentialet $\mathrm{i}$ visse af de fremhævede, musikalske gestalter, og hermed fokuseres også musikkens representerende funktion. Således kan m2's relativt hurtige, uregelmæssige staccerede anslag opleves som et onomatopoietikon (eller en sonisk anafon) for en fjern travl telegraf eller skrivemaskine ${ }^{28}$ - motiveret af åbningens panoramabillede over redaktionsstudiet, hvor flere mennesker i baggrunden sidder bøjet over tastaturer. Yderligere er åbningens animerede grafik med til at etablere indtryk af travlhed og informationsstrøm - det er som om, de vertikale strenge er ledninger, der ligefrem 'dirrer' af spænding. Senere giver m4's rytme ${ }^{29}$ og artikulation (hurtige, marcato anslag) lignende indtryk - denne gang blot 'tættere på' (mere fremtrædende i lydbilledet) end flimmermotivets fjerne sværmen. Mere generelt finder det tilsyneladende travle, hektiske redaktionsarbejde genklang i musikkens hurtige og højt intensiverede puls; pulsmarkeringens prægnante foredrag af lilletrommen (m5) associerer i sammenhæng hermed militærmusik (en art genre-synecdoche); det giver indtryk af præcision og alvorsfuldhed ${ }^{30}$. De musikalske baggrundsgestalter under åbningen (m1 og m2) og forskræppet (m5 og m6) rummer i deres 'rumlen' også forestillingen om vedvarenhed, 'urgency' og 'recency' - nyhederne strømmer til stadighed ind (indtrykket forstærkes i øvrigt senere i Nyhederne, da endnu en omgang forskræp ledsages af samme musik som $\mathrm{i}$ indledningens forskræp). Betydningsmæssigt tilbyder bevægelsen fra 'fjern, ude, vag' til 'nær, inde, klar' den forestilling, at redaktionen er en flittigt filtrerende enhed, der skaber prægnans på en baggrund af ulmende kaos.

Af øvrige repræsentative forhold er især en stilmæssig inspiration af den symfoniske senromantik (jf. note 24) af relevans. Denne stil-indikator er medvirkende til at iscenesætte nyhederne under en vis dramatik - seeren kan siges at blive suget ind i et dramatiseret og følelsesberusende univers; stilen inviterer til følelsesmæssigt engagement. Dette muliggøres i høj grad af vores musikalske socialisering: Vi har alle indoptaget det senromantiske idiom som varm 'musikalsk modermælk' via filmmusikkens massive anknytning til stilen ${ }^{31}$. En 
anden implikation ved musikken som stil-indikator er i øvrigt, at det senromantiske idiom synes at konnotere 'højagtelse' eller 'legitim smag' ${ }^{\text {'32 }}$ under sammenligning med for eksempel wienerklassisk stil (som snarere opfattes som 'let' og 'underholdende'). Dette kan sociokulturelt dels begrundes i musikkens datidige sociale funktioner, men dels hænger det også sammen med, at den musikalske socialisering af denne stil (i dag) ofte finder sted i forbindelse med mere trivielle kontekster (såsom supermarkedet, restauranten eller ved telefonen) under sammenligning med det mere udtryksfortættede og højstemte filmunivers.

\section{Nyhedernes musik som markedskommunikation}

Fokuseres nu afslutningsvist på de markedskommunikative implikationer ved Nyhedernes musik, er det karakteristisk, at musikken fungerer som en egenreklame. Musikken er én af de markedskommunikative fangarme, der skal etablere og fastholde seer-opmærksomhed og gøre udsendelsen identificerbar og konkurrencedygtig i forhold til: 1) andre udsendelser på kanalen; 2) andre TV-stationer og deres (tilsvarende) udsendelser; 3) øvrige medier (avis, radio, internet) og aktuelle gøremål (f.eks. madlavning og spisning).

I forhold til en intra-kanal profilering gælder det, at udsendelsen på Nyhederne er omkranset af diverse 'ikke-programmer'. Især reklameblokkene udbyder, i reklamespots en masse, et væld af mere eller mindre fantasifulde, påtrængende $o g$ genkendelige jingles ${ }^{33}$. Som det 'fremmedlegeme' reklameblokken er, er disse musikforekomster, for kanalen, svært kontrollerbare, og de udgør den 'støj', som Nyhedernes musik må råbe igennem. Dermed bliver særligt musikkens presentationsfunktion relevant i forbindelse med den intra-kanale profilering. Reklamerne besværliggør etableringen af en særegen musikalsk profil, men kanalens egne 'ikke-programmer' (trailers, forskræp o. lign.) er en mulighed for at præparere nyhedernes indtræden - i det aktuelle tilfælde ved at skabe kontrast i overgangen til Nyhedernes åbning: et jazzet, tilbagelænet groove (el-piano og kantslag på lilletromme) danner musikalsk baggrund for kanalstemmens præsentation af aftenens senere programmer. Men også kanalens 'rigtige programmer' må kommes i hu; vigtigt er det indholdsmæssigt at signalere, at nu starter et faktaprogram $^{34}$. Nyhedernes symfonisk dramatiske og hektiske musikalske gestaltning bliver dermed en afgrænsning til andre programtypers musik (f.eks. sportens mere ungdommelige idiom (især dance-, disco-og rock-inspireret) og andre faktaprogrammers mere afdæmpede og rolige udtryk); men samtidig kompromitteres Nyhedernes objektivitet og saglighed betydeligt ${ }^{35}$.

Dermed har vi bevæget over mod musikkens inter-kanale profilering. Et dilemma melder sig umiddelbart her: på samme tid må musikken både signalere 'nyheder' og '(s) erlige nyheder' - et dilemma, som afføder både konvergerende og divergerende profileringsstrategier ${ }^{36}$. Her er det særligt musikkens representationsfunktion, der bliver relevant. Profileringen kommer i første række til at signalere og give forventning om en bestemt tilgang, form og håndtering, snarere end det bliver et signal om det specifikke udvalg af nyheder: Dels kan musikken eventuelt animere nyhedsværtens fremtoning (især stemmeføring, mimik) og præsentation $^{37}$ og dels - hvilket er tydeligere - har Nyhedernes indslag (jf. f.eks. analyse i Hjarvard, 2000) tendens til at være mere dramatiserende og underholdningspræget, end tilfældet er med den fremmeste konkurrent: DR. Musikken kan her opfattes som forankrende. Interessant er det i denne forbindelse, at Nyhederne i 1988 lanceredes som et alternativ til TV-avisen. Ifølge TV2's tidligere nyhedschefer skulle Nyhederne i højere grad (end TV-avisens angiveligt noget tunge og monumentale fremtoning) bære præg af (folke)nærhed - i både indhold og fortælling - og samtidig være mindre officiel i fremtoning. Blandt andet afspejler dette sig i en øget orientering om indenrigsstof på bekostning af udenrigsstof ${ }^{38}$. Den aktuelle jingle repræsenterer imidlertid snarere lyden af det 'internationale', 'hektiske' og 'globale', og jinglen kan således høres som en dansk tilnærmelse til den 'internationale lyd af nyheder', som den er klangligt defineret i vægtige, dagsordenssættende amerikanske nyhedsmedier (især GNN) ${ }^{39}$.

I forhold til en ekstra-kanal profilering gælder det, at Nyhederne skal kunne identificeres i en videre kontekst, der implicerer andre medier samt den umiddelbare audiovisuelle kontekst (hvor andre lydlige indtryk trænger sig på fra radio, stereoanlæg, el-koger, samtaler o. lign.). Her er musikkens presentationsfunktion igen særlig relevant. Den relativt lange indledning ${ }^{40}-$ og den omtalte musikalske iscenesættelse af 'fjern til nær' - er formuleret 
ind i en tid, da TV-mediet også fungerer som baggrund for andre gøremål (madlavning, strygning, m.m.). Seerens opmærksomhed forudsættes ikke at være skærpet fra start; den forsøges således hidkaldt og skærpet via et musikalsk 'indsugningsforløb'. Karakteristisk er det i denne sammenhæng også, at der, som nævnt, optræder forskræp med musikledsagelse inden i nyhederne; det er som om seerens opmærksomhed forsøges vedligeholdt, og at oplevelser af 'stilstand' og 'snigende kedsomhed' forsøges overdøvet. I en videre forstand tilnærmer den øgede musikmængde i Nyhederne sig et omfang, da nyhederne kan fungere som 'soundtrack'; Nyhedernes musik må her ikke blot forstås som en iscenesættelse af nyhederne, men også som et medium til iscenesættelse af sig selv. Nyhederne og dennes musik bliver i denne forståelse en ressource, som tilhøreren kan bruge til at lade sine eventuelt monotont oplevede dagligdagsgøremål 'omfavne' og 'indhylle' med sammenhæng og mening; nyhedsmusikken omfavner, som analyseret, med dramatik, intensitet og nærvær ${ }^{41}$.

\section{Afrunding}

Nyhedernes musik bidrager vægtigt på sammenbindende, presenterende og representerende vis: Musikken knytter billedsekvenser sammen, den agerer 'lytfang' for vores opmærksomhed, og den karakteriserer i vist omfang dét, som opmærksomheden ønskes rettet imod.

I analysen er det, på baggrund af en række identificerede musemer, blandt andet forsøgt anhørliggjort, at musikken i Nyhederne bidrager til at illudere en bevægelse ind mod en travl og punktlig redaktion; selvom musikken principielt hele tiden er såkaldt ekstradiegetisk (underlagt), giver især de onomatopoietiske udtryk indtryk af nære lydkilder i den aktuelle, billedligt fremstillede kontekst (såkaldt diegetisk musik eller her: 'redaktionens musik'). Det må pointeres, at musikken sagtens kunne substitueres af en anden og stadig 'fungere' på et syntaktisk niveau, men på et semantisk niveau ville små musematiske ændringer imidlertid medføre store udtryksmæssige ændringer; f.eks. kunne det fremtrædende, opadstræbende motiv $(\mathrm{m} 4)$ hypotetisk substitueres med en omvending (så opadgående bliver nedadgående), og det musikalske imperativ ville ændre sig fra ca. 'Ret dig op og hør efter' til ca. 'Sæt dig ned og slap af'.

I forhold tilandre markedskommunikative tiltag kan musik betragtes som havende en privilegeret status; dels kan vi ikke nemt lukke ørene for den, og dels er den i stand til på kort tid at mobilisere et omfattende betydningspotentiale. Nyhedernes musik repræsenterer imidlertid kun delvist musiks markedskommunikative evner. I en vis forstand tillader genren -nyheds(re)præsentationsmusik - således kun en vis grad af eksperimenteren og sofistikerethed i forbindelse med brugen af musik (jf. f.eks. de tidligere omtalte divergerende og især konvergerende profileringsstrategier) - seeren må ikke være i tvivl om, at nu starter Nyhederne (det musikalske bidrag kan i sammenhæng hermed siges at forholde sig overvejende forankrende). I andre markedskommunikative genrer kan musikken i højere grad bruges udfordrende, forledende og overlistende (og dermed i højere grad aflosende). Dette gælder, for en umiddelbar betragtning, især TV-reklamen, og et indgående studium af musikkens funktioner i TV-reklamer ville givetvis udvide forståelsen for musiks markedskommunikative evner. 


\section{Skemaoversigt}

\begin{tabular}{|c|c|c|c|c|c|}
\hline 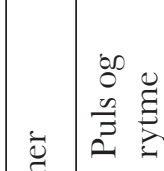 & 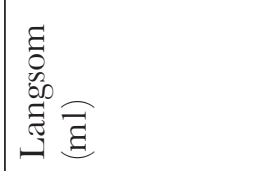 & 总怘 & 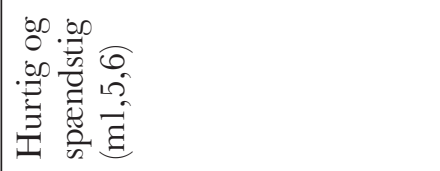 & 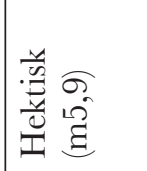 & 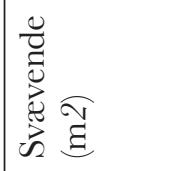 \\
\hline 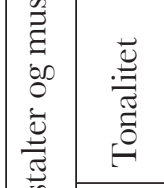 & 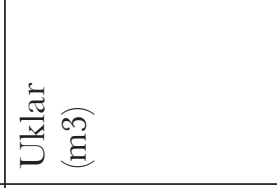 & 胥 & 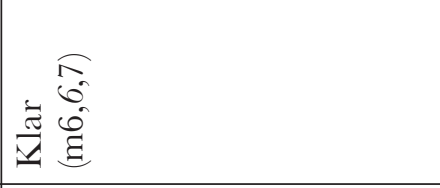 & 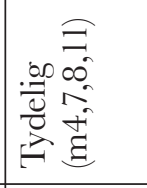 & है बै \\
\hline 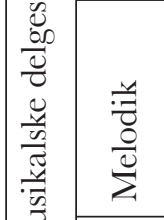 & 离 & 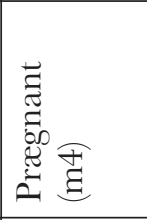 & 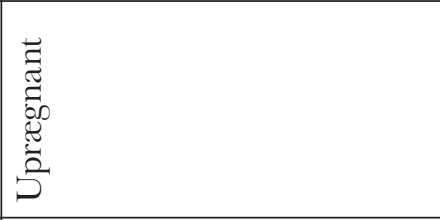 & 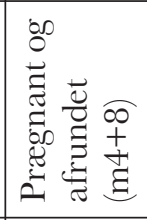 & हुँ \\
\hline 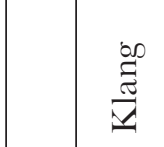 & 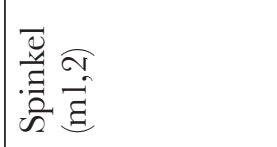 & 总屆 & 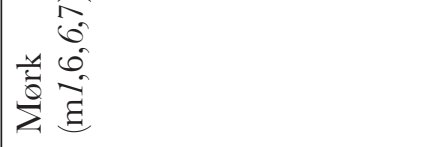 & 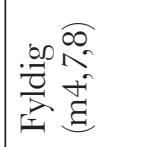 & 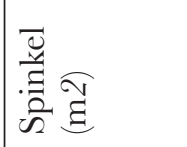 \\
\hline 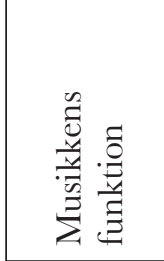 & 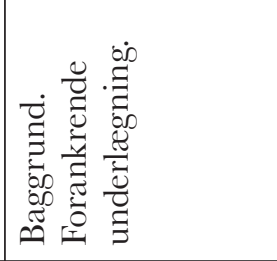 & 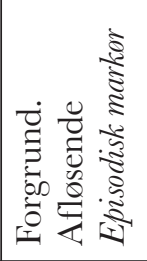 & 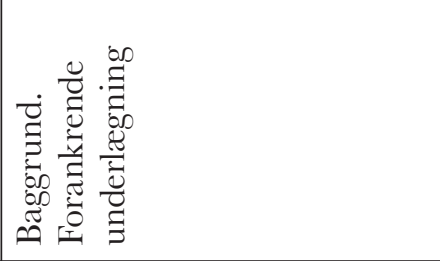 & 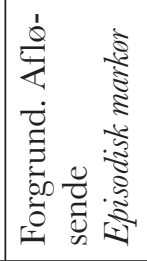 & 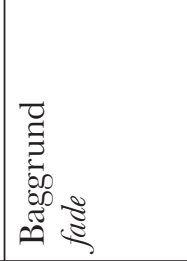 \\
\hline $\begin{array}{l}\text { 节 } \\
\stackrel{n}{n}\end{array}$ & 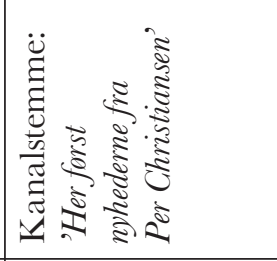 & 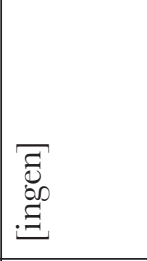 & 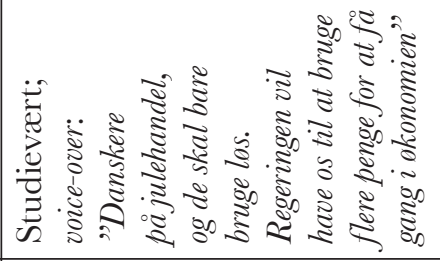 & 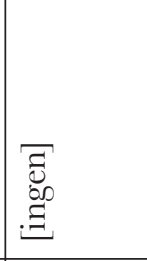 & 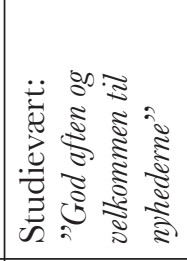 \\
\hline 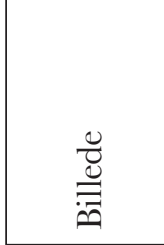 & 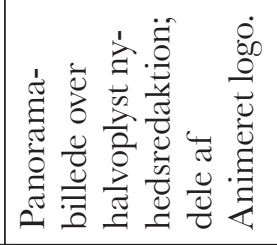 & 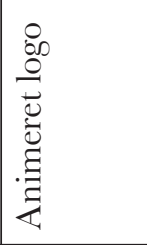 & 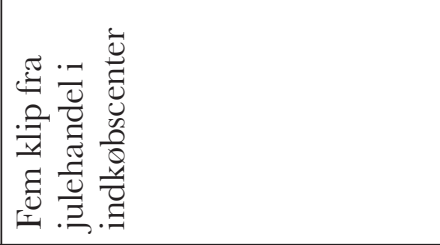 & 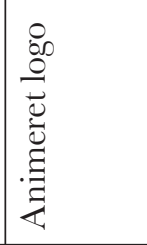 & 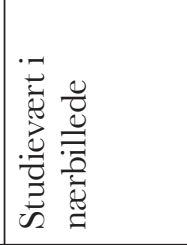 \\
\hline 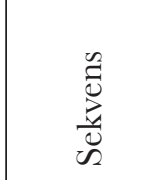 & 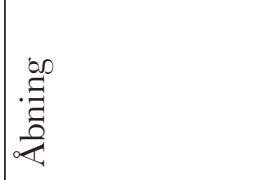 & 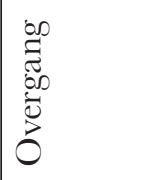 & 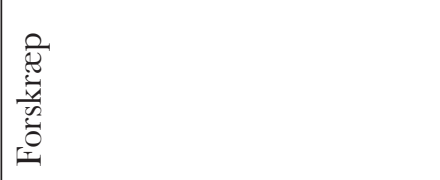 & 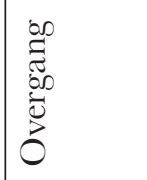 & 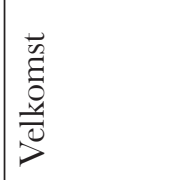 \\
\hline 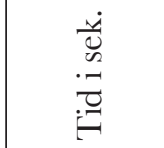 & s. & $\begin{array}{l}0 \\
1 \\
1\end{array}$ & $\frac{7}{1}$ & $\begin{array}{l}\stackrel{a}{2} \\
\stackrel{1}{I}\end{array}$ & 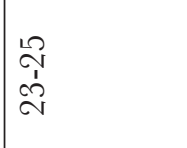 \\
\hline
\end{tabular}




\section{Litteratur}

Benestad, F. (1976). Musikk og tanke. Oslo: Aschehoug.

Bourdieu, P. (1984). Distinction - a social critique of the judgement of taste. London: Routledge

Bourdieu, P. (1990). The logic of practice. Stanford: Stanford University Press.

Bridge, F. (1921). The old cryes of London. London: Novello.

Bruner, G. (1990). Music, Mood and Marketing. In fournal of Marketing. Oct., s. 94-104.

Clayton, M., Herbert, T. \& Middleton, R. (Eds.) (2003). The cultural study of music. London:

Routledge.

Cooke, D. (1959). The language of music. Oxford: Oxford University Press.

Davies, S. (2001). Philosophical perspectives on music's expressiveness. In Juslin, P. \& Sloboda, J.

(Eds.), Music and emotion (s. 23-44)

DeNora, T.(1986). How is extra-Musical meaning possible? Music as a place for 'work'. Sociological Theory, 4, s. 84-94.

DeNora, T.(2000). Music in everyday life. Cambridge: Cambridge University Press

Gammond, P. (1991). Oxford Companion to Popular Music. Oxford: Oxford University Press.

Hjarvad, S. (2000). Nærhedens nyheder. In TV2 på skermen (red. Bruun, Frandsen \&

Søndergaard), p.131-160. København: Samfundslitteratur

Jantzen C. \& Stigel, J. (1995). Reklamen i dansk landsdekkende TV. København: Statsministeriets

Medieudvalg.

Kerman, J. (1985). Musicology. London: Fontana.

Langer, S. (1979). Philosophy in a new key. Harvard: Harvard University Press.

Larsen, P. (1988). Musik og moderne billedfiktioner. In Kultur og klasse. Nr. 60, s. 33-53. Medusa

Larsen, T. \& Maegaard, J. (1981). Indforing i romantisk harmonik. København: Engstrøm \& Sødring.

Leo, H. (1999). Musik im Fernsehwerbespot. Frankfurt: Peter Lang

Nattiez,J.-J. (1990). Music and discourse - toward a semiology of music. Princeton: Princeton

University Press

Nielsen, F.V. (1998). Almen musikdidaktik. København: Akademisk Forlag.

Prendergast, R. (1992). Film music - a neglected art. New York: Norton

Steiner-Hall, D. (1987). Musik in der Fernsehwerbung. Frankfurt: R.G. Fischer Verlag.

Stillwell, R.J. (2003). Advertising, music in. In New Grove, Oxford University Press (internet-version: www.grovemusic.com (Macy, L.(red.))

Straarup, O. (1974). Funtionel musik. Århus: Publimus

Tagg, Ph. (1979a). Kojak- 50 seconds of television music. Göteborg. Musikvetenskapliga Institutionen.

Tagg, Ph. (1979b). "Fernando". In Dansk Musiktidsskrift. Nr. 3, s. 124-156.

Tagg, Ph. (1998). "Introductory notes to the semiotics of music. Internetversion". Hentet (24.10.2003) fra: www.tagg.org/xpdfs/semiotug.pdf.
Van Leeuwen, T. (1989). "Changed times, changes tunes: Music and the ideology of the news". In Australian Television. Tulloch \& Turner (red.). Sydney: Allen \& Unwin.

\section{Noter}

\section{Gallup TV-Meter}

2 Dermed skal musik, som i andre sammenhænge, og mere eller mindre tilfældigt og partikulært, optræder i nyhederne ikke behandles (til oversigt kan tre kategorier udledes: musik som stofområde, musik som incidental eller diegetisk forekommende og musik som underlægning (sidstnævnte typisk i afrundingen af $\mathrm{Ny}$ hederne under den 'lette, sjove' historie; f.eks. d. 19/12, 2003, da der afsluttes med et indslag om havenisser under akkompagnement af julemusik)).

3 Med få variationer i instrumenteringen (især i de første måneder) og syntaks (musikken klinger kortest tid til 19:00-nyhederne, da der her kun præsenteres ét nyhedsindslag i forskræppet; 22-nyhederne præsenterer til sammenligning tre)

4 Vurderet i december, 2003. Nyhederne er dog kun marginalt mere set end DR's TV-avis (således overværede et gennemsnit på 810.000 21-nyhederne i uge 50).

5 I det hele taget har kun få undersøgelser fokuseret på nyhedsmusik (f.eks. Leeuwen, 1989), og mere generelt berøres hermed det forhold, at 'funktionel musik' til stadighed ikke er genstand for megen forskningsmæssig interesse; dette begrædes også løbende hos de relativt fåtallige forskere, som faktisk er interesserede (f.eks. Straarup (1974), Tagg (1979b), Bruner (1990), Leo (1999) og Stilwell (2003)).

6 For oversigt se Benestad (1978) og Davies (2001).

7 Eksempelvis i 16- og 1700-tallets musikalske affektlere samt senere lignende udtryk (jf. f.eks. den sigende titel på Cooke, 1959).

8 F.eks. hedder det om jinglen i Oxford Companion to Popular Music: "[...] name now given to those insidious but fortunately brief musical interludes [...]" (Gammond, 1991, s. 297).

9 Det afhænger selvfølgelig i nogen grad af definitionen af musik. Her skal 'lyd som er menneskeorganiseret og menneskeoplevet' være en minimal definition. Jf. Tagg (1998, s. 16-19) for yderligere afgrænsninger.

10 Med inspiration i Bourdieu (1990, s. 55-56, 60)

11 'Mening' og 'betydning' bruges ikke her om to klart adskilte fænomener: 'mening' om subjektets oplevelse af sammenhæng og 'betydning' om objektets intersubjektivt anerkendte og genkendelige reference.

12 Dette forhold har blandt andet givet anledning til at betragte musik som særligt privilegeret i forhold til at illudere og fremelske følelser: "[...] music can reveal the nature of feelings with a detail and truth that language cannot approach" (Langer, 1979, s. 235). Opfattelsen kendes også i den populære aforisme: "Musik er følelsernes sprog", som dog er misvisende så langt som 'sprog' tages for bogstaveligt.

13 DeNora (2000); f.eks. "[...] musical affect is constitut- 
ed reflexively" (s. 33) og "[...] to speak 'about' things [music] is, to constitute those things" (s. 38).

14 At musikken kan understøtte og fastholde (forankre) henholdsvis modsige, nuancere (afløsning) billedsidens betydning.

15 Sådan som også Larsen har påpeget og analyseret det (Larsen, 1988)

16 Semiotik bruges her overordnet om et 'systematisk studium af tegns betydning'. Det ligger uden for grænserne af artiklen at måtte præsentere og diskutere (musik)semiotiske bidrag mere indgående. Analysen vil snarere være inspireret af et semiotisk begrebsapparat til forståelse for aktuelle musikalske udtryks betydningspotentiale.

17 Musik har nok betydningsadskillende, men ikke betydningsbærende enheder (jf. note 18).

18 Den musikalske pendant til lingvistikkens morfem. Musik kan ikke, som sproget, siges at have fonemer (Tagg, 1998, s. 31); eksempelvis vil en melodistump (morfem) lyde ens uafhængig af om den synges i c- eller d-dur; tonerne (fonemer) ville imidlertid være forskellige.

19 Selve identificeringen af musemer vil for nærværende (som typisk i Taggs egne analyser; f.eks. 1979b) være baseret på såkaldt 'hermeneutisk intuition'. Om et musikalsk udsagn kan kvalificeres som musem er således i høj grad afhængig af fingerspitzgefühl; en vigtig tommelfingerregel er (til supplement af det allerede, i Tagg-citatet, nævnte), at det musikalske udtryk skal ændre sig mærkbart om et påberåbt musem hypotetisk substitueres. Det betyder også, at ikke alle musikalske gestalter i det aktuelle musikalske udsagn nødvendigvis må kendes som musemer (for yderligere metodeovervejelser og validitetsproblematikker se Tagg, 1979a, s. 73-77). I det følgende skal musemer identificeres dels i skikkelse af melodiske motiver, men også rytmer, harmoniske progressioner og melodiske motivsammensætninger kan være relevante at identificere som selvstændige enheder; herved berøres musemers vertikale og horisontale komplekse sammenkædninger og afhængighed (hos Tagg benævnt henholdsvis: paradigmatic museme compounds og syntagmatic museme compounds). I analysen skal identificerede musemer, for overskueligheds skyld, nummereres (f.eks.: ml), og efterfølgende skal eventuelle musem-variationer kursiveres (f.eks. m1).

20 Her må det pointeres, at Langers forståelse af 'symbol', tilsyneladende inspireret af Saussure, svarer nogenlunde til det, Peirce benævner 'ikon'. Peirces brug af 'symbol' svarer til Sausurres 'arbitrære tegn'.

${ }^{21}$ Grundlaget for analysen er 19:00-Nyhederne d. 11/12. Analysen vil basere sig på det auditive udtryk (et partitur (transskriberet af forfatteren selv) kan lånes ved henvendelse). Til støtte under læsningen af analysen, er indledningssekvensen sammenfattet i et skema.

22 Teknikken, med detail-synkronicitet mellem musik og billede, kaldes, undertiden nedsættende, 'mickey-mousing' (eks. Prendergast, 1992). Musikken er her med til at dynamisere og dramatisere bevægelse i billedet.

23 Begreb om et kortfattet, højprofileret musikalsk (eventuelt instrumentalt) forløb. I angelsaksisk sprogbrug er jinglen oprindelig benævnelse for den lidt skingre, raslende lyd, der affødes af små lette metalgenstande, som rystes mod hinanden (som nøgler i et knippel). Jinglen som musikalsk fænomen kan opfattes som havende en historisk rod i de gennemtrængende gaderåb, som handlende på markeder kunne iscenesætte for at tiltrække opmærksomhed fra forbipasserende (jf. til eksemplificering Bridge, 1921).

24 As-duren indtræder som en tonikavariantafledning. Akkorden får imidlertid en udholdt eksponering, og derfor kan den forstås som optrædende med en mere selvstændig funktion; nemlig som tonikavariants $l e-$ detonevekselklang eller som en såkaldt neapolitanisering af tonika - virkningen er en udtryksfuld farvning af tonika (for yderligere funktionsbeskrivelse se Larsen \& Maegaard, 1981). Den harmoniske vending har et senromantisk, symfonisk tilsnit (en betragtning som understøttes af den aktuelle instrumentation); harmoniske virkemidler er generelt i den senromantiske stil (ca.1850-1920) fremtrædende som udtryksartikulation, og harmonikken kan i denne periode siges at emancipere sig som en selvstændig udtryksform (under sammenligning med klassikken (komponister som Haydn, Mozart og Beethoven), da harmoniske progressioner snarere tjener et formdannende formål).

25 Tilføjet ikke blot som en ekstra kæk og inciterende markering af musikkens afrunding, men også som tydeligt signal til studieværten om, at nu skal velkomstspeak starte (ifølge musikkens medkomponist, Anders Mechelburg; under samtale d. 23/12, 2003).

26 Denne aften $(11 / 12)$ kan det yderligere forstås sådan, at indledningssekvensen konstruerer en stadig mere individualiseret seeridentitet: fra åbningens 'man', over forskræppets 'os' ('[...] finansministeren vil hav os til at bruge flere penge [...]") til velkomstens illudering af et 'jeg' via den direkte 'iøjnesættelse'.

27 Må forstås som perspektiver, som analytisk fokuserer fremtrædende forhold ved det aktuelle musikudsagn. Musikalske udtryk er ikke 'parameterkonglomerater', sådan at enkelte parametre skulle kunne manipuleres, mens andre holdes konstante (som det ellers gerne impliceres i marketingsforskningen (jf. f.eks. Bruner, 1990)). De nævnte delgestalter er indvævet i hinanden, og f.eks. vil et melodisk udsagn også have klanglige, pulsmæssige og tonalitetsmæssige implikationer. I den konkrete analyse har det den betydning, at musemer kan perspektiveres på flere måder; f.eks. er signal-motivet $(\mathrm{m} 4)$ både definerende i forhold til den melodiske profil, men det bidrager også væsentligt til tonalitetsbestemmelse, klangbillede og pulsfornemmelse (jf. skemaet).

28 En musikalsk skikkelse som, i forskellige gevandter, optræder i mange nyhedsjingles (også bemærket i Leeuwen, 1989)

29 Et lille kuriosum er det, at motivets rytmiske profil danner tallet 3 i morsealfabetet: kort-kort-kort-langlang (måske havde tallet 2 - udtrykt k-k-l-l-l - været mere passende)

30 Lilletrommen har en lang tradition for anvendelse i militærsammenhæng. Med dets prægnante og smældende artikulation repræsenterede (stadig i dag i mindre omfang) den en vigtig kommunikationsform i både krigs- og fredstid, og signaler kunne f.eks. for- 
dre: 'angrib', 'til våben', 'indstil skydning', 'reveille' eller være markeringer af march-rutiner. I 1800-tallet dukkede manualer frem med specifikke signaler og ledsagelsesrutiner. Brug af lilletromme i forbindelse med militær- og signalfunktion finder i kunstmusikken dramatisk udtryk hos blandt andre Händel ("Royal Fireworks") og Beethoven ("Wellingtons Seig").

31 Etableret i Hollywoods 1930-50'erne, da filmkomponister som Steiner, Korngold og Newman lader sig kraftigt inspirere af senromantikere som Wagner, R. Strauss, Mahler, Verdi og Puccini (jf. Prendergast, 1992, for uddybning). Mere konkret, i forhold til nyhedernes ouverture, tilbyder for eksempel den musikalske dramatisering (i overgangen til velkomsten) associationer til en symfonisk finale. Et eksempel til sammenligning kunne være de afsluttende momenter i ouverturen til Wagners 'Die Meistersinger von Nürnberg'; hos Wagner agerer musikken (også i c-dur, i øvrigt) pompøs og monumental iscenesættelse og signalement af de forestående begivenheder.

32 Her inspireret af Bourdieus studier af musikalske genrer og stilarters markante betydning som klassifikations- og distinktionsmarkør (jf. Bourdieu, 1984).

33 Et interessant forhold er det i denne forbindelse, at signalmotivet (m4) synes kraftigt inspireret af Intel's jingle. Således er m4's fire første toner, hvad angår interval og rytme, identisk med Intel-jinglen.

34 'Fakta' må tages med forbehold. Der kan f.eks. identificeres et vist indholdsmæssigt overlap mellem de to (ikke)programtyper: reklame og nyheder; således er nyhedsaspektet jo en vigtig del af reklameringen, ligesom reklamen undertiden vinder, mere subtil, indpas i nyhederne; f.eks. når et dokumentarprogram senere samme aften annonceres i nyhederne under et indslag - behændigt tilvejebragt netop denne dag.

35 Denne dramatisering kan i øvrigt høres som noget nyt under sammenligning med Nyhedernes første jingles svævende og drømmende udtryk og den senestes (frem til d. 1/5, 1998) korte og mere poppede fremtoning.

36 Dette kan i øvrigt forstås som kendetegnende for annoncering i al almindelighed (jf. Jantzen \& Stigel, 1995).

37 I det aktuelle tilfælde kan Per Christiansens artikulation opfattes som præget af en lidt anstrengt marcato under velkomsten. Om det så skyldes musikken, Per Christiansen-idiomatik, TV-presenter-idiomatik eller den aktuelle nyheds herlighedsværdi skal ikke her undersøges nærmere.

38 Jf. Hjarvard, 2000 for analyse og data.

39 Til sammenligning fremtoner DR's aktuelle jingle (december, 2003) i øvrigt mindre dramatiseret ved bl.a. ikke at benytte (lille)trommer.

40 Tidligere har indledningssekvensen kun varet 4-5 sekunder (jf. de to tidligere omtalte jingles på TV2).

${ }^{41}$ Om nyhederne og dennes musik rent faktisk bruges sådan bredt set er ikke undersøgt og må for nuværende fremstå som hypotese. Hypotesen bygger dels på egne erfaringer og dels på studier af DeNora (2000), hvor lignende musikforbrugsmønstre analyseres og diskuteres.

Nicolai Jørgensgaard Graakjær er cand.mag. i musik og psykologi og arbejder som undervisningsadjunkt ved Institut for Kommunikation, Aalborg Universitet. 